\title{
Types of Moral Consciousness
}

\section{Svetlana Pavlovna Paramonova}

Professor of society science chair, Solikamsk State Pedagogical Institute, extension of Perm State Science Research University

Professor of Sociology and Political Science Chair, Perm National Research Polytechnic University

Severnaya Street, 44, Solikamsk, Russian Federation

\section{Doi:10.5901/mjss.2015.v6n5s4p84}

\section{Abstract}

The path of virtue is based on the readiness to self discipline and moral course of action, to self-preservation and selfdevelopment in the process of mastering of nature and social forces. The moral pattern of communitarianist is happiness, which mined by the labor. He is intellectual, optimist, follower of the free will. Transition type - is two-faced Janus. He turns his face to his heads, or to the collective. Hedonist is our comfort I, and he is conformist. The sensual pleasure is the highest good for him. For pragmatist the highest good is technology, logic, technical interpretation of though, than the call of duty. In the process of mastering of social reality by the individuals, and production of identification strategies, types of moral consciousness are playing the role of latent structures in habitus.

Keywords: Types of moral consciousness: communitarian, transitional type, hedonist, pragmatist.

\section{Introduction}

Dynamics of moral consciousness incarnates in institutional and procedural dialectics. Social essence of morality is communitarity, adopted or on individualistic either on collective base. It incarnates in active essence of person: creativity, pragmatics, hedonics. Thesis of increasing of rationality lays on the boarder of XIX-XX centuries in context of extreme individualism becomes dysfunctional in XXI century. New vector is global communitarity. Communitarity means connection of morality and sociality.

The founding father of French sociology Emile Durkheim introduced term 'sociology of morality'. His idea to measure the condition of moral consciousness with specimens (patterns) was incarnate by Polish researcher Mariia Ossovska by the examples of belles-letter in 1949 (Ossovska M., 1987).

Twenty five years later, the prerequisite of new typology of moral consciousness became the lecture of lan Shepanskii in Polish Sociological Association «About Values of Polish Intelligentsia». He emphasized three types of values: feudal (oriented to idleness), pragmatic (capitalistic, oriented to equivalent of salary), and third type - (orientation to the value of labor and creativity). The last constituted small group of Polish technical intelligentsia. Polish sociology was in touch with American sociology. Z.I. Fainburg, the head of Perm school of Sociology, after his science journey to Poland, reported Shepansky's lecture to sociologists of Perm city in Polytechnic Institute. Aristotle had said: accept the Beginning, prove the rest.

The foundation of typology, which was worked out by us, is division into communitarianity and individualism, the plan and the market, balanced development and spontaneity. The last are the two interdependent forms of the optimal development of the society at the stage of industrialism. The violation of the balance leads to stagnation, or to chaos. The denial of the market lay in the Stalin's model of political economy; the denial of the plan lay in the economic conception of F. Hayek (Hayek F.A., 1999). From the point of view of Etzioni, market is not the automatic regulator of individual relations of exchange and it doesn't lead to general harmony. The market is mostly the conflict of interests; it contains not only atomized individuals, and atomized groups. These groups are capable to influence to politics and economics (Etzioni A., 1988.). Twenty years later Z. Bauman put sacramental question «Does the richness of the few benefit us all?» (Bauman Z., 2013). French authors L. Boltanskii and E. Chiapello notice: «Social critics become modernistic, if it has an emphasis on inequality; it becomes anti-modernistic if it goes against individualism, showing the lack of social cohesion» (Boltanskii L., Chiapello E., 2011).

On the other hand, at the social-philosophical level it was proved by the author that the self-preservation (Mach E., 2012) and the self-development (Orlov V.V., 1974) of the society depend on possibility of self-control of the society over the correlation parity of creativity and reproduction. Fundamental terms are given by Mach E. and Orlov V.V. If reproduction predominates, the society will be driven towards stagnation, if the uncontrolled-by-anything creativity 
dominates, chaos is inevitable. Every type of society, Eastern or Western, has its type of moral consciousness: individualistic or communitarianistic. John Urry thinks that face-to-face contacts increase social capital, increase life expectancy and promote economic activity by mutual support (Urry J., 2007).

Criterion of Novelty: The novelty of research lies in the first time measuring of types of moral consciousness in regions of Middle Russia, Ural and Siberia. Moreover, within 35 years we could watch the dynamic of moral consciousness of Russian society: society of social orientation, society of 'perestroika', and society of reforms.

The main difference from intuitive guesswork of journalists, politicians, ethicist, that we have reliable sociological instrument of research (Paramonova S., 2012). This typology was so attractive to some ethicist, that they were noticed in plagiarism, and that was said to them openly in conference.

Using the method of Okkam, the principle, that the essences should not be multiplied more than necessary in the combination of two model of the destiny in different choices, we managed to define the types of moral consciousness: the communitarianist, the transitional type, the hedonist and the pragmatist. The received profile from eight types of fates may be regarded by distinguishing this or that group (Paramonova S., 1998/2014).

\section{Research Methods}

The object of research is institute of morality. The model of research of institutional norms could be types of moral consciousness. In the basis of these types there are three features: the active essence of a person, the attitude to labor and to other person, as to the aim, or as to the device, and historical succession of morality. The types of moral consciousness in the examinations were received in the following way: in the process of interrogation of people from different enterprises. They choose the model of the destiny of some person, in this or that way identifying himself with him. Olshanskii used the method of choosing biography in 1960-ies in Moscow in the Institute of Sociology (Olshanskii V. B., 1966). This method is traditional for the Western-European sociology. The identification of understanding of the destiny-biography was covered by the procedure of validation (examination of foundation) between author and respondent.

Well-found socio-ethic typology of individual could become background for measuring conditions of moral consciousness in any place (in collective, region, state). Comparison of groups allows watching horizontal dynamics and time changing of moral norms displays vertical dynamics. Groups detailed by types of moral consciousness are the subject of research. Author takes a few instrumental criterions, which reflect specific of moral phenomena. The method of social research is interview and questionnaire (Paramonova S., 2012). During 1980-2012 for our research we took 34 establishments, $\mathrm{N}=11111$ by the example of Middle Ural regions

\section{Characteristics of Types of Moral Consciousness}

The humane purposes of the society encountered the limitation of satisfaction of needs stipulated by a low rate of scientific and technological progress. We have attempted, at least at a first approximation, to reveal the basic tendencies of the development of moral consciousness in the collectives of enterprises, establishments and educational facilities. The statics of the types of moral consciousness is researched through the following spheres of life activity in the collectives and outside them: a) the labor moral, b) the moral of the sphere of social-political activity, c) the moral of the family and household relations, d) the moral norms and values in the sphere of culture.

The definition of the types of moral consciousness is carried out by revealing one form of consciousness through another, a more obvious one. A number of test questions were used for this purpose. There are no less than eight questions, defining the motivation of the choice of attitude to the enterprise, the forms of ownership, the preferred system of moral, the comprehension of freedom, justice, life and labor values, the attitude to the facts of cultural life of the society, the motives of rendering assistance to others etc.

\subsection{Communitarianist}

Communitarianist keeps a fragile equilibrium between the norms, oriented to active creativity, and the new background expectations of the society: the principle of payment in accordance with labor and the equality of initial possibilities on the one hand, and the equality of all in the face of the law, on the other hand. Communitarist answers the challenge of the time with an active help in different life and working situations equally to those who ask for help and those who need help. His ability to self-development is expressed in his understanding of freedom as internal purposefulness, the realization of the abilities, in spite of the external circumstances. 
The personal characteristic of communitarist type. The true history of a person considers the aspiration to change the life, to plan it consciously. The personal characteristics of communitarianist are defined first of all by the fact that such type of consciousness and behaviour women show more often than men. That fact proves the data obtained from mixed and 'female' enterprises. Men are usually pragmatists.

The education and profession do not have a strict connection with the type of moral consciousness. Communitarianist has a family and is an authority for children. He tries to keep the feeling of love in family. The ability of the person to make good and kind actions is supposed to be a free moral act and to create kind things is available to everybody, but in the reality this is the peculiarity of communitarianists.

The labor for a worker is a valuable process. From data of research we can interpret the picture of values of different types of moral consciousness to the enterprises. For pragmatist it is only a source of earning money, for communitarianist it is a life place, where he can realise his creative potential and plans for future life, where his authority is formed.

He understanding of justice in among the technical intelligentsia is reduced to the formula - the equality of all at the face of the law. And it is understood in the following context - the equality in front the law is not yet the equality in life, it means, that not everyone uses the rights; however they are given to everybody. For example, J. Rawls has suggested two principles to perfect relations: the first one is the principle of justice, which demands the priority of freedom. Freedom is considered to be a basic social value. The second one is 'the rule of maximum', which has a strong democratic charge. Any benefit of a member of the society, who is in a worse situation than others, should outweigh any loss of the well-off people (Rawls J., 2010).

\subsection{The transitional type of moral consciousness}

His activity is especially widely manifested in big cities. In the conditions of the changes of the values of the society women showed 'spiritual migration' to the group of transitional type, and constituted a third part, which is not characteristic of the ethics of the sex in the organic epoch, but it is typical for the transitional period. It constitutes a half among the marginal types in the working groups of the society in the quantitative sense.

The characteristics of the transitional type of moral consciousness are largely defined by his place in the social structure of the society. Most often he is a leader at the most important, initial level of management. In his value attitude to labor in comparison with other transitional types he has revealed the highest orientation to creation and self-perfecting, which is similar to communitarianist. The high orientation to earnings unites him with pragmatist. The spirituality in the consciousness of the transitional type creates continually, charged with 'duality'. His emotional conviction in the aspiration «'to have' instead of to be'» here are only substantiated by the rationalizations (Fromm E., 2014).

\subsection{Hedonist}

The sense of life of hedonist is getting pleasure and enjoyment. The faith dominates in his consciousness. Hedonist gravitates towards family and narrow circle of friends. They have a higher education. By the social origin they come from humanitarian intelligentsia. They refer themselves to the middle-paid employees. Their places of work are the state enterprises. If hedonist changes his work, he comes to service sphere.

The personal features of hedonist . Mostly women are drawn to hedonism. The hedonism of women is connected with their fertile period. However where there is a favorable mode for the men, due to the limitation of the acceptance of women, the share of the hedonists-men becomes bigger, than among the women.

Among hedonists there are mostly healthy women and men. On the one hand here there is the factor of their origin and the self-removal from the intensive work; on the other hand hedonist consciously maintains his health. The representatives of this group by the type of moral consciousness are mostly worried about the sanitary-hygienic working conditions at the enterprise and the ecological situation.

There are more hedonists than pragmatists among the youth. Very often hedonists have a low qualifying category and the lowest the parameters of performance standards. Hedonists praise the values of cooperative nature more, than the values of competitive nature, which characterize a person as a rival. The criterion of choice in the case of discomfort for them will always be the opinion of the collective, which they listen to keenly and adherently.

Hedonists help only when they are asked for help. In getting higher education hedonists concede to the transitional type and communitarianist. In the case when hedonism is actualized over the limits of the possible, the activity of a person and whole communities will lead to their destruction.

Since hedonist is driven towards the values of traditional society, justice in his understanding is inseparably 
connected with the moral qualities, which are to predominate in the life of people. It is impossible to be fair, without being humane. His orientations are directed to the trust in the authority.

\subsection{Pragmatist}

Pragmatist is the bearer of the model of economic rationality of the society. He believes that the principle of historical justice is the equality of all in front of the law. Besides, four components of freedom shape his spirit: to do everything that is not forbidden by the law; the inner subjective freedom; the non-interference of the State into the private life of a person, and also the availability of the money, the mammon, the property.

The closer to the financial and industrial centers the community is situated, the higher is the level of pragmatism of the interrogated respondents. In general pragmatists are men. Women have constituted the smallest part.

The personal characteristic of pragmatist. Very often pragmatists come from the families where parents belonged to the underpaid groups of the society. A part of pragmatists is from the circle of intelligentsia. This group has promoted at the enterprise due to their education. Another part of pragmatists is from the families of unskilled workers. The values of individual material interest were common to these groups, opposite in their educational level.

People with different types of moral consciousness show themselves in friendship in different ways. The circle of contacts of pragmatists is limited to 'the necessary people'. Pragmatist renders his help mostly to those people, who either ask for assistance or who can answer equivalently. Men-pragmatists have revealed a high satisfaction with their promotion at each enterprise.

The priority of the personal interest over the common interest (the morality of individualism) in the socialpsychological moods is fraught with the anti social moral principles. The moral responsibility, which used to comprise professional ethics, family decency, the self-discipline of personality, now means the search for a convenient niche for the survival and the freedom of principles.

Very often pragmatists come from the families where parents belonged to the underpaid groups of the society. A part of pragmatists is from the circle of intelligentsia. This group has promoted at the enterprise due to their education. Another part of pragmatists is from the families of unskilled workers. The values of individual material interest were common to these groups, opposite in their educational level.

People with different types of moral consciousness show themselves in friendship in different ways. The circle of contacts of pragmatists is limited to 'the necessary people'. Pragmatist renders his help mostly to those people, who either ask for assistance or who can answer equivalently. Men-pragmatists have revealed a high satisfaction with their promotion at each enterprise. They have fast promotional track. Pragmatist usually takes role of manager on enterprise, school or high schools.

The level of those provided with comfortable housing conditions coincides with the number of those who have a full family with children. More than two thirds of pragmatists are happy in the family. Less than a third lives with their parents. Pragmatists do not usually live in dormitory.

On the whole the examination of the leading groups of the technocracy shows the following. In transition society men begin to pay high tribute to family and began to display kinds of communitarianists. Again, when society comes to stability, men with technical education have revealed the tendency to pragmatism in their moral consciousness and behavior.

Women have shown the classical type of distribution of the values of collectivism and hedonism. In society, which goes through social cataclysm, women become pragmatists. She catches any work to feed a family. And when the situation becomes stable, she obtains. It is the indirect sign of stabilization of moral consciousness.

The poorer the status of the professionals has more gravitation towards the collective norms of consciousness. The higher the status is the more is the gravitation towards individualism. Hedonism showing the orientation to the natural values of the comfortable existence. If hedonism becomes center of values of society, as history teaches us, such process were the beginnings of the downfall of great civilizations.

There was revealed a strong tendency to lowering the value of the family in the life of professionals, which characterizes countries of modern civilization. The presence of people, who live in civil marriage, proves this tendency. The social system, which does not raise the stimuli for perfecting the conditions, has adapted in another way - by lowering the status of the family which has always been the institute of self-preservation and self-development of the society.

On the contrary, individualists (pragmatists and hedonists) adapted first to the dysfunctions of production and having greatly benefited from it in the former society. They have become conflicting groups, requiring the maintenance of equivalent relations at the present time. The measure of pragmatism is determined. The number of pragmatists has 
increased from a quarter to a third in the adult generation and constitutes more than a half of the interrogated representatives of the younger generation in modernes Russian society. Socioeconomics unites those who doesn't like neoclassic theory, theory of rationality, and theory of public social choice. Socio-Economics is interdisciplinary bridge between exchange and structure. It unites research of rational reasons with values and senses (Economicheskaya sotsiologiya: teoriya i istoriya, 2012).

In the conditions of the transition the ethics of sex exhibits itself in the opposite way. It is especially noticeable in the dynamics of moral consciousness and the conduct of the youth: girls begin to be drawn to pragmatism, and young man - to communitarianism. French authors continued this discussion: «Activity for the good of all is emancipating: it emancipates from the pressure of egoistic interests. Freedom is indispensable condition of peoples dignity in civil world, as far as it guarantee expression of aspiration of citizens to the integration» (Boltanskii L., Teveno L., 2013).

Having concentrated in themselves different qualities of the types of moral consciousness, they, as a group, began to be enriched by the power of developed personal qualities of communitarianists and pragmatists. They were capable to understand others in the critical situation and - by their effort to help with their deeds, advice, and participation in the period of reforms.

Hedonists have demonstrated a high moral firmness in the preference of traditional socialist values. The ambivalence as a form of the attitude to the world has 4 not entered the consciousness and the conduct of hedonists. A. Gouldner sneers: for funcionalist, as for Plato, as for all religious tradition, human being is angel-without-his-wings, which has to live in ascesis, and has to hold in his pleasure with help of «socialization» (Gouldner A., 2003).

A society accepts the direction of development when it overcomes the chaos. Ethic-creation predominates over ethic-chaos only when the management and the self-organization give the possibility of self-preservation and selfdevelopment of the society, with a dynamic resolution of conflicts. The escape of the society from the crisis is only possible after the society acquires the moral orientations, convincing everyone (Paramonova S., 1998/2014).

\section{Conclusion}

Practical sense research. Not all groups by types of moral consciousness can be manipulated in the same way. Communitarians are the most adaptive in modern Russia. Pragmatics, which didn't get the due equivalent of remuneration of their labor and activity, have latent protest potential.

Communitarians do not accept favoritism, clanship, team type of management. Pragmatics and hedonists think that favoritism is acceptable way of advancement in society. With the changing of values, leaders of collectivistic society conceive of themselves as social outcast. Hedonics feel comfortable. The lowering of labour potential, science and organizational activity, orientation to hedonism mean the movement back from progress to regress. To the same conclusion on the basis of empirical researches of advancement of specialists in oil and gas complex modern authors come (Efendiev A.G., Sorokin P.S., 2014). The manifestation of hedonics tendencies is inoffensive process. From the domination of ideology of hedonism the Greek-Roman civilization perished. O. Shpengler foresaw the end of Europe. Under the impacts of waves of migration and their injection into the consumer society (modern hedonism) all West European civilization could degenerate (Golovnev A.V., 2015).

We have attempted to receive new results in the social-ethical awareness of the reality by the method of implantation of the moral-typological approach to the old trunk of sociological problems.

Nowadays the world still seems to live in male culture, thus the right of force has a traditional characteristic. The paradox is that the movement to the modernization of relations realizes itself through the intensification of traditionalism or neotraditionalism.

The moral situation was only sometimes intuitively guessed, but was not revealed at all. Having received the sociological estimation, from the sphere of the chaos it moves into the sphere of the conscious, objectively evaluated knowledge. This contributes to the priority of the greater justice in the moral relations in the collectives. Whatever critical conclusions would be, they are better, than the ignorance of the social community and the personalities in their moral status. As the investigations have proved, the types of moral consciousness are not a lesser, but a bigger social reality, than the types, revealed by M. Weber, at the beginning of the century.

\section{References}

Bauman, Z. (2015). Idet li bogatstvo nemnogich na polsu vsem prochim? Translated from English N. Edelman. - M.: Isdatelstvo Institut'a Gaydar'a. - 108 p. [in Russian]

Boltanskii, L., Chiapello, E. (2011). Noviy duh kapitalism'a. Translated from fr. by O. Volchek, Y. Kalagina, S. Ryndin, S. Fokin. - M.: 
Novoe literaturnoe obozrenie. - 976 p. [in Russian]

Boltanskii, L., Teveno, L. (2013). Kritika i obosnovanie spravedlivosty: Translated from fr. by O.V. Koveneva. - M.: Novoe literaturnoe obozrenie, -576 p. [in Russian]

Durkheim, E. (1991).O razdelenii obzchestvennogo truda. Metod sotsiologii.. Bukinisticheskoe izdaniye. - M.: Nauka. - 576 p. [in Russian]

Economicheskaya sotsiologiya: teoriya i istoriya: (2012) /Pod.red. Veselov Y.V., Kapustkina E. V., (i dr.) - Skt-Peterburg: NestorIstoriya. - Pp. 180 -192. [in Russian]

Efendiev, A.G., Sorokin, P.S. (2014). Kariera rukovoditeley v rossiyskih bisnes-organisaziyah kak sotsialniy phenomen: opyt teoreticheskogo i empiricheskogo analisa IXIV aprelskaya mezdunarodnaya konferenziya po problemam razvitiya ekonomiki v 4$h$ kn. otv. red. E.G. Yasin. - M.: Izdatelstvo Vysshey Shkolii Ekonomiki, - p. 300-310. [in Russian] http://www.academia. edu/70 43371/Interpretation_and_Explanation_in_Cultural_Sociology._A_Three-Step_Model_of_Interpretation_and_Its_Empirical Application

Etzioni, A. (1995). Moralnii aspect: na puti k novoy ekonomike /Noprosy philosophii. - № 10. - Pp. 67- 84. [in Russian]

Fromm, E. (2014). Dusha zcheloveka. Revolutsiya nadezd: Translated from English by T. Panfilova, V. Saks. - M.: AST Astrel. - 172 p. [in Russian]

Golovnev, A.V. (2015). Phenomen kolonisatsii. - Ekaterinburg: UrO RAN, 2015. - 592 p. [in Russian]

Gouldner, A. (2003). Nastupauzchiy krisis zapadnoy sociologii: Translated from English by A.S. Fomin, V.V. Kusnezov, M.G. Ermakova. - Skt-Peterburg: Nauka, 575 p. [in Russian]

Hayek, F.A. (1991). Proishozhdenie i deystvie nashey morali: problema nauki /IEkonomika i organisaziya promyishlennogo proizvodstva. - № 12. - Pp. 177-197. [in Russian]

Mach, E. (2012). Princyp sokhraneniia raboty. Istiriia I koren ego. - M.: KomKniga. 70 p. [in Russian]

Olshanskii, V.B. (1966). Lichnost i sotsialnye tsennosti //Sotsiologiya v SSSR. - M.: Mysl. T. 1. - Pp. 470-530. [in Russian]

Orlov, V.V. (1974). Materiia, razvitiie, chelovek. - Perm.: Perm State University. 394 p. [in Russian]

Ossovska, M. (1949/1987). Rytsar' i Burzhua. Issledovaniia po istorii morali. Translated from Polnish by K.V. Dushenko. - M.: Progress. $-528 \mathrm{~s}$. [in Russian]

Paramonova, S.P. (2012). Dynamica Moralnogo Soznaniya (VVedenie v sociologiyu morali). - Saarbruken: LAP LAMBERT Academic Publishing GmbH \& Co. KG, 2012. - 443 p. [in Russian].

Paramonova, S.P. (1998/2014) Types of Young People's Moral Consciousness. Russian Education \& Society 1998-10-01 (Teylor \& Francis Group publisced. Trans.) on line 08 Dec. 2014 http://www.tandfonline.com/doi/abs/10.2753/RES1060-9393401034

Rolz, J. (2010). Teoriya spravedlivosti. Translated from English V. Karpovich, A. Shevchenko. - LKI. - 536 p. [in Russian]

Urry, J. (2012). Mobilnosti: Translated from English be A.V. Lasarev. - M.: Praksis. 2012. - 576 p. [in Russian] 